\title{
Climatic response of Picea glauca seedlings in a forest-prairie ecotone of western Canada
}

\author{
Sophan CHHIN ${ }^{1,2 *}$, G. Geoff WANG ${ }^{1,3}$ \\ ${ }^{1}$ Department of Biology and the Centre for Forest Interdisciplinary Research, The University of Winnipeg, Winnipeg, Manitoba, Canada R3B 2E9 \\ ${ }^{2}$ Present address: Department of Renewable Resources, 4-42 Earth Sciences Building, University of Alberta, Edmonton, Alberta, Canada T662E3 \\ ${ }^{3}$ Present address: Department of Forestry and Natural Resources, Clemson University, 261 Lehotsky Hall, Clemson, South Carolina,
} USA, 29634-0317

(Received 2 May 2007; accepted 16 July 2007)

\begin{abstract}
We examined radial and height growth-climate relationships of juvenile white spruce in three contrasting microenvironments within a prairieforest ecotone of western Canada. The three microenvironments were (1) the understory of mature trembling aspen (Populus tremuloides Michx.) groves, (2) the understory of mature white spruce (Picea glauca (Moench) Voss) tree islands, and (3) the open prairie outside the influence of mature trees. Interannual patterns in radial and height growth from each of the three environments were related to the regional climate (temperature and precipitation). The growth-climate relationships identified indicated that growth of juvenile white spruce was conditioned primarily by direct moisture stress during the wettest month of the year, namely June precipitation in the current growing season $(t)$. The growth of juvenile white spruce also responded secondarily to moisture stress indirectly induced by high temperatures in June $(t)$. The results support the general understanding that the southern limit of conifer species in western Canada is controlled mainly by moisture stress either directly by low precipitation or indirectly due to temperature-induced drought stress.
\end{abstract}

dendrochronology / drought stress / height growth / radial growth / southern distribution limit / white spruce

Résumé - Réponse climatique de semis de Picea glauca dans l'écotone prairie-forêt dans l'ouest du Canada. Nous avons examiné les relations climat-croissance radiale et croissance en hauteur de jeunes Picea glauca dans trois microenvironnements contrastés de l'écotone prairie-forêt de l'ouest du Canada. Les trois microenvironnements étaient : (1) un sous-bois de bosquets de trembles matures (Populus tremuloïdes Michx.), (2) un sous-bois d'îlots de Picea glauca (Moench) Voss) matures et (3) la prairie ouverte en dehors de l'influence des arbres. Les patrons interannuels de croissance radiale et de croissance en hauteur de chacun des trois environnements ont été reliés au climat régional (température et précipitations). Les relations croissance-climat qui ont été identifiées indiquent que la croissance des jeunes Picea glauca était essentiellement conditionnée directement par un stress de sécheresse pendant le mois le plus humide de l'année, c'est-à-dire les précipitations du mois de juin de l'année de croissance en cours $(t)$. La croissance des jeunes Picea glauca a aussi secondairement répondu au stress hydrique indirectement induit par les fortes températures de juin $(t)$. Les résultats confortent l'interprétation générale de la limite sud des conifères dans l'ouest du Canada, qui est principalement contrôlée par la sécheresse induite directement par les faibles précipitations ou indirectement par les températures élevées.

dendrochronologie / stress du à la sècheresse / croissance en hauteur / croissance radiale / limite sud de distribution / Picea glauca

\section{INTRODUCTION}

Projections of future climate change based on climate models indicate a warming of $1.4{ }^{\circ} \mathrm{C}-5.8{ }^{\circ} \mathrm{C}$ upon a doubling of atmospheric $\mathrm{CO}_{2}$ emissions by 2071-2100 [14]. The effect of global warming is expected to be most apparent at mid- to high-latitudes, and for disjunct tree populations and tree species at their edge of distribution [20]. In the prairie provinces of western Canada, the southern limit of conifer species occurs in the aspen parkland, which is believed to be controlled mainly by moisture deficiency [13] either directly by low precipitation or indirectly by temperature-induced drought stress $[3,5]$. Vegetation in the aspen parkland is dominated by trembling aspen (Populus tremuloides Michx.) which exists as continuous forest or as groves intermixed with

* Corresponding author: sophan.chhin@ualberta.ca prairie [2]. The aspen parkland is a transitional vegetation zone (ecotone) between prairie to the south and boreal forest to the north $[2,35]$. The environment of the parkland is believed to characterize the future boreal forest under a warmer climate [13]. The prospect of global warming and its induced changes in disturbance regimes (e.g., fire) is expected to lead to the northward expansion of the grassland environment at the expense of reduced productivity of the boreal forest due to dieback and fragmentation. Consequently, studies on the present interaction between vegetation and climate in the aspen parkland will help us to better understand future climatevegetation interactions in the southern boreal forest [13].

In Canada, most studies on the effect of climatic fluctuations on white spruce (Picea glauca (Moench) Voss) growth at its northern [1, 28] and southern limit [5, 22] of distribution have focused mainly on the effect of climate on the radial 
growth pattern of old trees. Few attempts have been made to examine the effect of regional climate on the radial growth of juvenile trees (e.g., [12]). It is customary in dendrochronological analysis to take stem disks or increment core samples at breast height [4]; however, sampling at breast height forfeits the analysis of the juvenile growth period of a tree prior to reaching breast height. Furthermore, most studies in the boreal forest [11, 17, 30] or the northern tree-line [25] have examined height growth patterns of juvenile trees mainly in relation to microclimate and/or to silvicultural treatments and not to regional climatic patterns $[7,10,18]$.

Growth responses to climate may be age-dependent [28]. For instance, unlike mature trees, juvenile trees have smaller root systems that generally occupy the upper soil horizons and thus do not have access to the stabler soil moisture and nutrient supply of deeper soil layers [12, 29]. It would be expected then that young trees would be more sensitive to climate than older trees. On the other hand, it has also been argued just as strongly that growth of tree species at their juvenile stage of development are primarily affected by microclimatic variation or stand dynamics [6] and are not sensitive to regional climatic patterns. Furthermore, as trees mature and increase in height there is increasing hydraulic resistance for the transport of water, photosynthate and hormones over larger distances; this would contribute to an increased sensitivity to climate in older trees [12, 29].

The objective of this study was to examine the climatic response of juvenile white spruce (hereafter referred to as white spruce seedlings) in three contrasting microenvironments within a prairie-forest ecotone of western Canada. These microenvironments were (1) the understory of mature trembling aspen groves, (2) the understory of mature white spruce tree islands, and (3) the open prairie outside the influence of mature trees. Interannual patterns in radial and height growth from each of the three environments were related to the regional climate. Since woody canopies generally modify the understory microclimate, including shading, reduced wind speed, lower soil temperature, and higher humidity [31], we hypothesised that juvenile white spruce from the open prairie would contain the clearest regional climate signal because of the lack of an influence of mature trees. This was based on the underlying assumption that the microclimate conditions in the shaded, cool habitats of the spruce island and aspen grove understory would limit evapotranspirational water loss and thus in turn moderate the hot and dry regional climate of the study area. We also hypothesised that radial growth would contain a stronger climate signal than height growth since during episodes of environmental stress (e.g., drought), radial growth generally receives lower priority than height growth for carbon allocation [15].

\section{MATERIALS AND METHODS}

\subsection{Study area}

The study was conducted in the Spruce Woods Provincial Park (SWPP), which is located in southwestern Manitoba (49 $40^{\prime} \mathrm{N} ; 99^{\circ}$ $15^{\prime} \mathrm{W}$; elevation $\left.=360 \mathrm{~m}\right)$ (Fig. 1$)$. According to spatially interpolated climate data for the SWPP over the reference period of 19712000 , the study area was characterized by average annual temperature of $2.9^{\circ} \mathrm{C}$ and average annual precipitation of $474.0 \mathrm{~mm}$ [32]. Precipitation peaks in June $(83 \mathrm{~mm})$, and temperature is highest in July, reaching a daily mean of $18.9{ }^{\circ} \mathrm{C}$ (Fig. 2). Vegetation in the park is characterized as the aspen-oak grove of the boreal forest region [21]. A sandhill prairie community unique to the aspen parkland is located in the SWPP and consists of trembling aspen intermixed with a disjunct population of white spruce at its southern limit of distribution [23]. The SWPP resides over an extensive belt of deltaic sands $\left(6500 \mathrm{~km}^{2}\right)$ created 12000 years B.P. when a predecessor of the Assiniboine River flowed into glacial Lake Agassiz [23].

\subsection{Field sampling}

The study was located in three mixed-grass prairie preserves north of the Assiniboine river: Picnic, Aspen Bluff, and Jackfish prairie (Fig. 1). Ten open prairie (OP) sites, ten white spruce islands (SI), and ten aspen groves (AG) were selected using aerial photographs and field reconnaissance. Four sites of each habitat were chosen in Picnic prairie and Aspen Bluff prairie, whereas two sites of each habitat were selected in Jackfish prairie.

Open prairie sites that contained more than six seedlings between 0.5 and $2 \mathrm{~m}$ tall clustered within a circular area of $10 \mathrm{~m}$ radius were selected. The seedling nearest to three randomly placed circular plots (1-m radius) was sampled in each open prairie site. In a white spruce island, a $12 \mathrm{~m}$ transect line was extended along the north side of the largest dominant tree (i.e., reference tree). The centre of three circular plots (1-m radius) were placed 4,8 , and $12 \mathrm{~m}$ from the reference tree along the transect line. The seedling nearest to the centre of each of the three circular plots was sampled in each spruce island. Aspen groves containing understory development of juvenile white spruce were selected. Three circular plots were randomly placed in each aspen grove and the seedling nearest to the centre of each circular plot was sampled.

\subsection{Sample processing and chronology development}

Height and root collar diameter (RCD) were recorded for each sampled seedling. A root collar section was taken from each sampled seedling and was prepared following standard dendrochronological techniques $[27,34]$. That is, all wood samples were sanded with progressively finer grades of sandpaper to highlight ring-width patterns. All root collar sections were crossdated under a binocular microscope to ensure accuracy of age determination. Crossdated root collar sections of white spruce seedlings were measured along two radii to the nearest $0.001 \mathrm{~mm}$ using a VELMEX (Bloomfield, New York) measuring system and the measurements for the two radii were averaged. The annual height growth of each destructively sampled seedling was determined by measuring the length of growth whorls that were delimited by terminal bud scars $[3,10]$. The raw ring width and height growth measurements were subsequently standardized by logarithmic transformation and then taking the first differences [16]. Radial and height growth index chronologies for each habitat were constructed by averaging the standardized series for each of the seedlings from each habitat. Radial and height growth chronologies were also constructed by combining seedlings from all habitats. Seedling attributes were compared between the three habitats using analysis of variance (ANOVA) followed by Tukey's multiple comparisons [33]. 

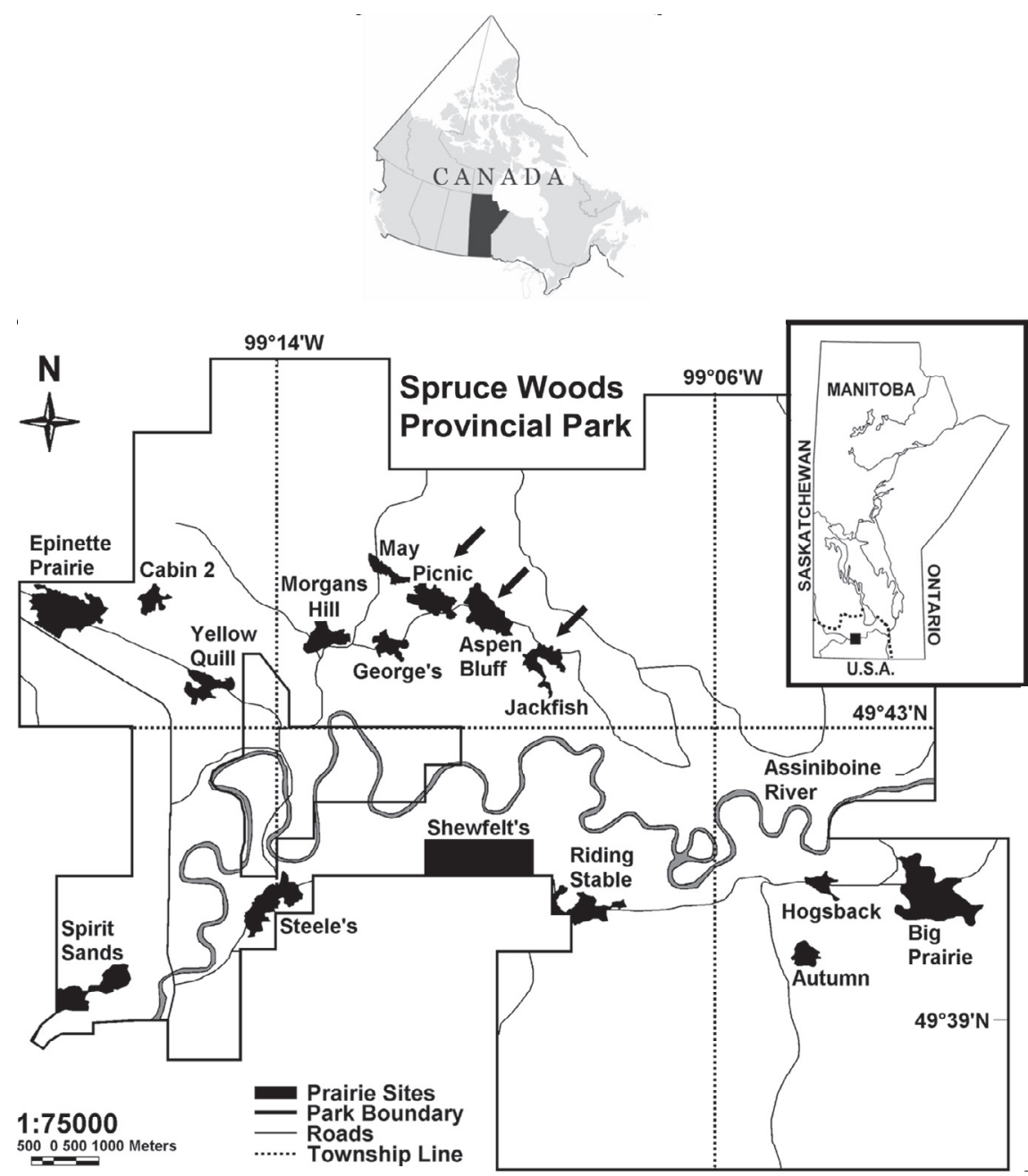

Figure 1. Regional setting of the Spruce Woods Provincial Park (SWPP) $(\bullet)$ in southwestern Manitoba shown in the inset map. The southern continuous limit of white spruce according to Farrar [8] is indicated by the dashed line. The arrows in the enlarged map of the SWPP (adapted from Schykulski and Moore [23]) indicate the mixed-grass prairie preserves in which the study was conducted.

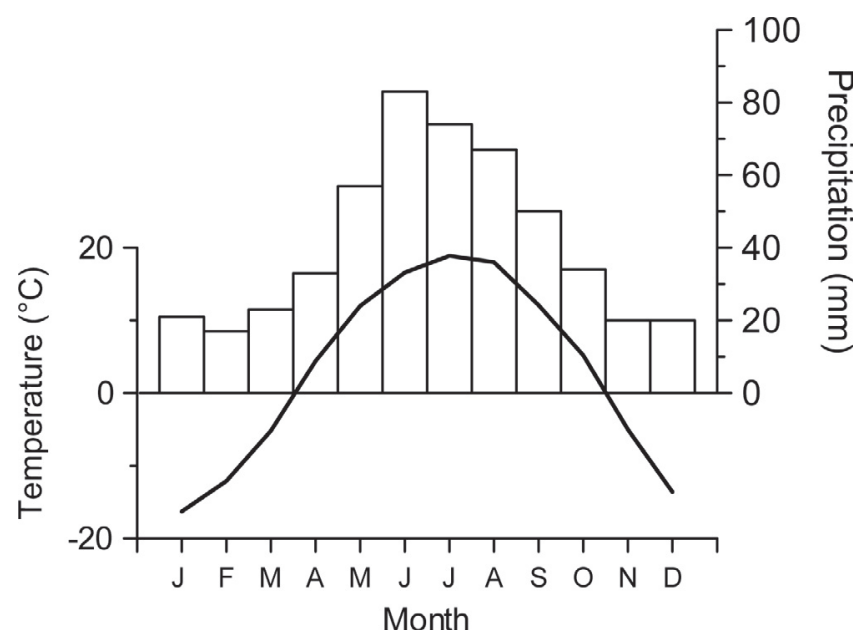

Figure 2. Climate diagram for the Spruce Woods Provincial Park showing mean monthly temperature (bold line) and total monthly precipitation (open bars) for the reference period of 1971-2000.

\subsection{Growth-climate relationships}

Spatially interpolated climate data was obtained for the SWPP using the program ClimatePP (version 3.0) [32]. ClimatePP provides output of monthly climate variables including mean monthly temperature and total monthly precipitation as a function of site location (latitude, longitude, and elevation) and covers the period of 19012002.

Growth-climate relationships were analyzed over a common interval for all radial and height growth chronologies from the three habitats such that the sample depth of a chronology consisted of at least 8 trees. This common interval corresponded to the period of 19851999. Growth-climate relationships were examined between the radial and height growth chronologies from each of the three habitats (and for all habitats combined) and each of the climatic variables (i.e., mean monthly temperature and total monthly precipitation) extending over two growing seasons from May of the previous year $(t-1)$ to August of the current year $(t)$ using Pearson correlation analysis.

We also examined the response of radial and height growth to key summer (May-August precipitation amounts) drought events during 
Table I. Attributes (mean $\pm 1 \mathrm{SE}$ ) and chronology characteristics of white spruce seedlings from three habitats (open prairies, white spruce tree islands, and trembling aspen groves).

\begin{tabular}{llll}
\hline Attribute & Open Prairie & Spruce Island & Aspen Grove \\
\hline Sample size (n) & 30 & 30 & 30 \\
Diameter (cm) & $2.60 \pm 0.34 \mathrm{a}$ & $2.05 \pm 0.14 \mathrm{a}$ & $1.92 \pm 0.13 \mathrm{a}$ \\
Height (cm) & $75.5 \pm 7.1 \mathrm{a}$ & $80.1 \pm 4.5 \mathrm{a}$ & $112.6 \pm 7.1 \mathrm{~b}$ \\
Age (year) & $13.2 \pm 0.9 \mathrm{a}$ & $16.1 \pm 0.7 \mathrm{ab}$ & $18.3 \pm 1.1 \mathrm{c}$ \\
Mean annual increment & & & $0.440 \pm 0.025 \mathrm{ab}$ \\
$\quad$ Ring width (mm) & $0.515 \pm 0.041 \mathrm{c}$ & $5.0 \pm 0.2 \mathrm{a}$ & $0.380 \pm 0.025 \mathrm{a}$ \\
$\quad$ Height (cm) & $5.2 \pm 0.2 \mathrm{ab}$ & 0.23 & $\mathrm{c}$ \\
Standard deviation & 0.23 & 0.25 & 0.14 \\
$\quad$ Radial growth index & 0.26 & & 0.23 \\
$\quad$ Height growth index & & & \\
\hline
\end{tabular}

For each attribute, habitats with different letters are significantly different at $P<0.05$. Standard deviation of the radial and height growth index chronologies was determined for the period of 1985-1999.

the period of 1985-1999. First, May-August precipitation amounts were converted into standardized Z-scores using the mean and standard deviation for the normal reference period of 1971-2000. A drought year was defined as having a Z-score $<-0.7$ (which corresponds to a drought year within the top quarter driest of all years). According to this criteria, three drought years were identified (i.e., 1988, 1992, and 1997). For each drought year, radial and height growth indices were compared between the three habitats using ANOVA followed by Tukey's multiple comparisons. A separate variance $t$ test [33] was used for comparisons between radial and height growth given the same drought year and habitat (or all habitats combined).

\section{RESULTS}

\subsection{Seedling attributes and chronology statistics}

Annual increment in ring width was greatest in $\mathrm{OP}$ seedlings followed by SI and AG seedlings (Tab. I). Annual increment in height growth was greater in AG seedlings compared to OP and SI seedlings $(P<0.05)$. The standard deviation (SD) of the AG radial growth chronology was less than in the other habitats, while the SD of the height growth chronologies was similar across all habitats.

\subsection{Growth-climate relationships}

With respect to mean temperature, although the correlations were not statistically significant at $P<0.05$, radial and height growth of $\mathrm{OP}(r=-0.50, P=0.056 ; r=-0.41, P=0.13$; respectively) and SI $(r=-0.41, P=0.13 ; r=-0.41, P=0.13$; respectively) seedlings showed the strongest correlation with June $(t)$ temperature (Fig. 3; Fig. 4). For AG seedlings, radial growth was significantly correlated with June $(t)$ temperature $(r=-0.56, P=0.029)$, and height growth had the strongest correlation with June $(\mathrm{t})$ temperature $(r=-0.38, P=0.17)$. For all habitats combined, radial growth was negatively related with June $(t)$ temperature $(r=-0.58, P=0.025)$; and the strongest correlation with height growth was also June $(t)$ temperature $(r=-0.44, P=0.10)$.
In terms of precipitation, radial and height growth of OP seedlings were positively correlated with June $(t)$ precipitation ( $r=0.77, P=0.00073 ; r=0.56, P=0.031$; respectively) (Fig. 5). Height growth of OP seedlings was also negatively associated with September $(t-1)$ precipitation $(r=-0.62$, $P=0.015)$. Although not statistically significant at $P<0.05$, radial growth of SI seedlings showed the strongest relationships with January $(t)(r=0.50, P=0.056)$ and June $(t)$ $(r=0.50, P=0.056)$ precipitation, while height growth of SI seedlings was most strongly associated with June $(t-1)$ precipitation $(r=0.47, P=0.074)$. For AG seedlings, radial growth was positively related to June $(t)$ precipitation $(r=0.61, P=0.015)$, and height growth was positively related to June $(t-1)$ precipitation $(r=0.54, P=0.039)$. For all habitats combined, radial growth was positively related with June $(t)$ precipitation $(r=0.75, P=0.0012)$; and height growth was negatively related with September $(t-1)$ precipitation $(r=-0.52, P=0.045)$ and positively related with June $(t-1)$ precipitation $(r=0.51, P=0.052)$.

According to the drought-year Z-scores, the 1997 drought was the driest followed by the 1988 and 1992 droughts (Tab. II). The 1988 drought resulted in consistent reductions in radial and height growth for all habitats; the reduction was most prominent in the radial growth of OP seedlings. The 1992 drought had the greatest impact on the radial and height growth of OP seedlings followed by SI and AG seedlings. The 1997 drought had the greatest impact on the radial growth of SI seedlings followed by OP and AG seedlings. The 1997 drought had a more negative impact on the height growth of AG seedlings compared to OP and SI seedlings. For each habitat or all habitats combined, the 1997 drought had a bigger impact on height than radial growth; this was especially the case for $\mathrm{OP}$ and $\mathrm{AG}$ seedlings.

\section{DISCUSSION}

White spruce seedlings responded mainly to June precipitation either in the current year (for the radial and height growth of OP seedlings and the radial growth of AG seedlings) or June precipitation of the prior growing season (for the height 

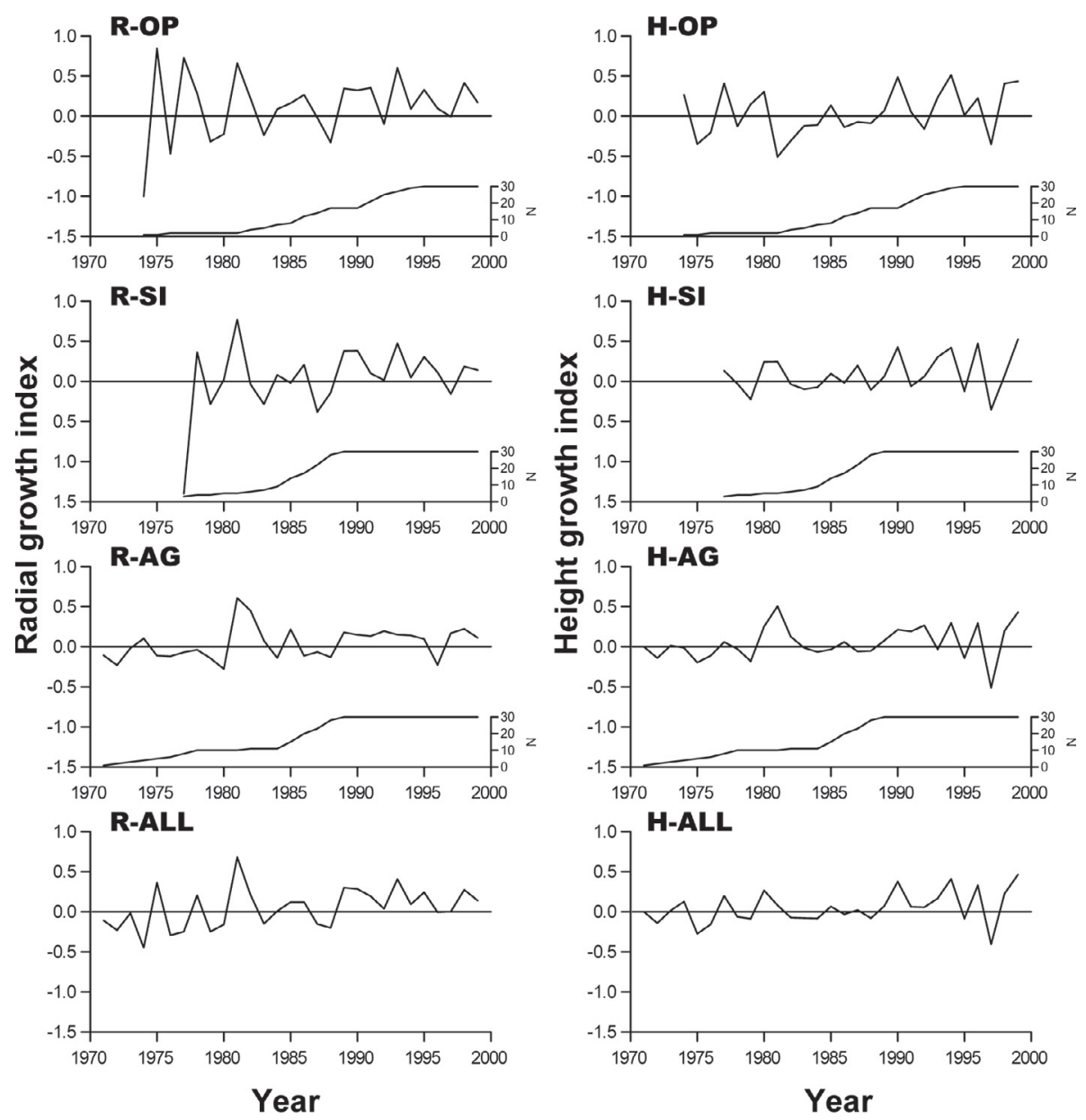

Figure 3. Radial $(\mathrm{R})$ and height $(\mathrm{H})$ growth chronologies of white spruce seedlings from three habitats (open prairies (OP), white spruce tree islands (SI), and trembling aspen groves (AG)) and for all habitats combined (ALL), and the corresponding sample size $(N=$ number of tree seedlings).

growth of AG seedlings) (Fig. 5). For all habitats combined, radial growth of seedlings mainly showed a positive association with June $(t)$ precipitation, and height growth was positively correlated with June $(t-1)$ precipitation. The lagged response of height growth to climatic conditions in June $(t-1)$ is related to the multi-year development of shoot growth [15]: climatic conditions in the year of bud formation $(t-1)$ affects the size of dormant buds, which in turn affects the amount of shoot growth in the year of bud expansion and shoot elongation $(t)$. Precipitation peaks in June according to the climate diagram for the SWPP (Fig. 2). Consequently, the results suggest that growth of seedlings is conditioned mainly by the amount of precipitation during the wettest month of the year. These results support the general understanding that the southern limit of conifers in the prairie provinces of Canada is governed mainly by moisture stress [5, 13, 35].

The driest drought year identified in our study was observed in 1997 which coincided with the high global temperatures associated with the 1997 to 1998 El Niño event [14]. El Niño events generally lead to a summer moisture deficit in western Canada [24]. The 1997 drought resulted in the largest reduc- tions in height growth of seedlings from all habitats (Tab. II). The second driest year for the study area was in 1988 which in turn corresponds to a well documented year of drought on the Canadian prairies [19]. The 1988 drought year resulted in consistent decreases in radial and height growth across all habitats. The negative impacts of these drought events further underscores the moisture sensitivity of white spruce seedlings at their southern limit of distribution.

Interannual patterns in mean monthly temperature and total monthly precipitation during the summer months in the SWPP are generally inversely related, particularly in the month of June ( $r=-0.53, P=0.041$; Fig. 6), resulting in summers that are generally both hot and dry. Further, past studies at the southern limit of white spruce have indicated that high temperatures, by increasing rates of evapotranspirational water loss, may indirectly induce moisture stress $[3,5]$. There was some indication that such was the case according to the negative relation between the radial growth of AG seedlings and June $(t)$ temperature (Fig. 4). While there were no statistically significant relationships with temperature in OP and SI seedlings, the strongest correlations were negative relationships between 

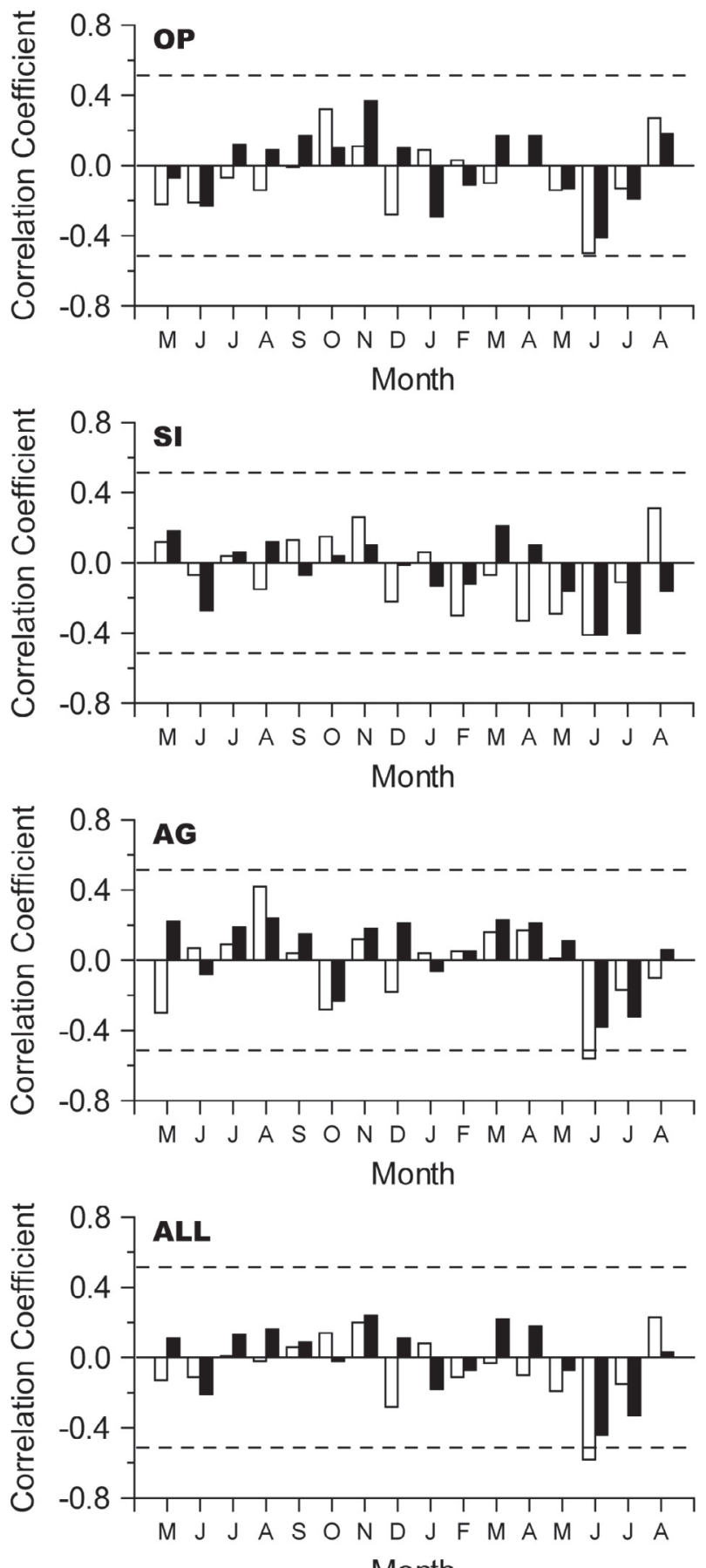

Month

Figure 4. Pearson correlation coefficients between the radial (open bars) and height (solid bars) growth chronologies of white spruce seedlings from three habitats (open prairies (OP), white spruce tree islands (SI), and trembling aspen groves (AG)) and for all habitats combined (ALL) with mean monthly temperature. The analysis period was 1985-1999. Dashed lines represent the threshold for significant correlations at $P<0.05$.
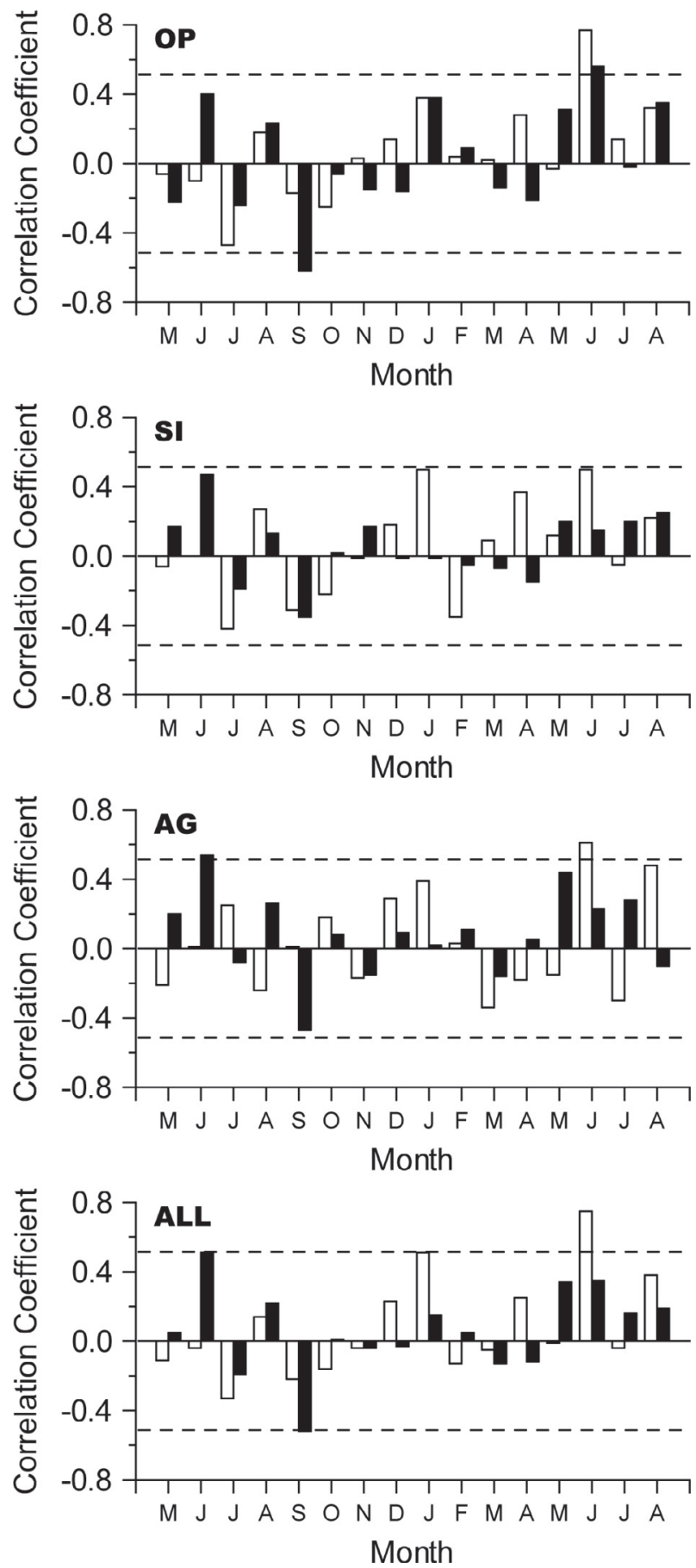

Figure 5. Pearson correlation coefficients between the radial (open bars) and height (solid bars) growth chronologies of white spruce seedlings from three habitats (open prairies (OP), white spruce tree islands (SI), and trembling aspen groves (AG)) and for all habitats combined (ALL) with total monthly precipitation. The analysis period was 1985-1999. Dashed lines represent the threshold for significant correlations at $P<0.05$. 
Table II. Impact of three drought years (DY) on the radial and height growth index (mean \pm 1 SE) of white spruce seedlings from three habitats (open prairies, white spruce tree islands, and trembling aspen groves) and all habitats combined (ALL).

\begin{tabular}{|c|c|c|c|c|c|}
\hline$\overline{D Y}$ & DY Z-score & Open Prairie & Spruce Island & Aspen Grove & ALL \\
\hline \multicolumn{6}{|c|}{ (a) Radial Growth } \\
\hline 1988 & -0.81 & $-0.33 \pm 0.12 \mathrm{a}$ & $-0.14 \pm 0.11 \mathrm{a}$ & $-0.13 \pm 0.12 \mathrm{a}$ & $-0.18 \pm 0.07$ \\
\hline 1992 & -0.75 & $-0.10 \pm 0.07 \mathrm{a}$ & $0.02 \pm 0.05 \mathrm{ab}$ & $0.20 \pm 0.08 \mathrm{~b}$ & $0.05 \pm 0.04$ \\
\hline \multicolumn{6}{|c|}{ (b) Height Growth } \\
\hline 1988 & -0.81 & $-0.09 \pm 0.12 \mathrm{a}$ & $-0.11 \pm 0.08 \mathrm{a}$ & $-0.05 \pm 0.11 \mathrm{a}$ & $-0.08 \pm 0.06$ \\
\hline 1992 & -0.75 & $-0.16 \pm 0.13 \mathrm{a}$ & $0.06 \pm 0.10 \mathrm{ab}$ & $0.27 \pm 0.10 \mathrm{~b}$ & $0.07 \pm 0.06$ \\
\hline
\end{tabular}

For each growth variable (radial or height) and drought-year, habitats with different letters are significantly different at $P<0.05$. An asterisk denotes a significant difference between radial and height growth index for the same drought-year and habitat or for all habitats combined.

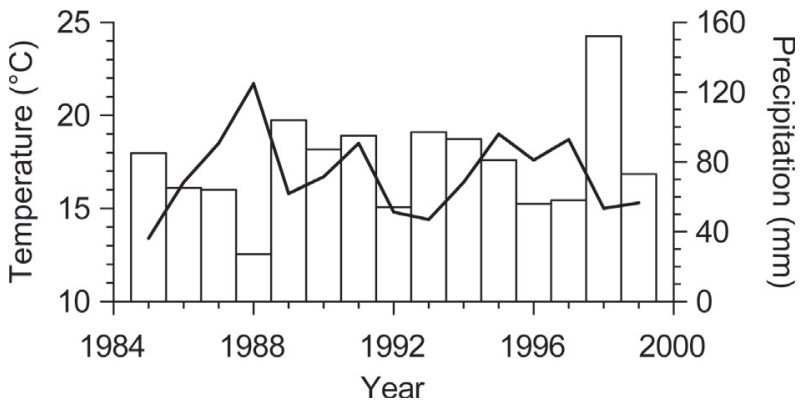

Figure 6. Climatic conditions in June for the Spruce Woods Provincial Park showing mean monthly temperature (bold line) and total monthly precipitation (open bars) for the period of 1985-1999.

radial and height growth to June $(t)$ temperature. Although not as hot as July $\left(18.9^{\circ} \mathrm{C}\right)$ and August $\left(18.0^{\circ} \mathrm{C}\right)$, June $\left(16.6^{\circ} \mathrm{C}\right)$ is the third hottest month of the year (Fig. 2). These results may suggest that seedlings are sensitive to temperature-induced drought stress in June $(t)$.

Radial and height growth of OP seedlings responded more strongly to June $(t)$ precipitation than those of AG and SI seedlings, which supported our initial hypothesis that OP seedlings would contain a clearer climate signal. Furthermore, the low standard deviation of the radial growth chronology of AG seedlings suggested a complacent interannual pattern in growth which in turn indirectly suggests a reduced sensitivity to climate [9]. Also, the impact of drought events were generally less severe for AG seedlings in terms of radial growth in all three drought years and for height growth in the 1988 and 1992 droughts. Nevertheless, it was partly unexpected to find significant climate relationships in AG seedlings particularly the clearer negative radial growth response to July temperature. This result suggests that the influence of mature aspen trees may not be entirely beneficial and that competition for resources such as light and water may be exacerbating the effect of direct and indirect drought stress in AG seedlings.

We also initially hypothesised that based on general hierarchy of carbon allocation [15], radial growth would be more sensitive to climate than height growth. This hypothesis was supported to some extent by our results. For instance when all habitats are combined, responses to precipitation and temperature were stronger in radial versus height growth particularly with respect to climatic conditions in June $(t)$. Furthermore, in assessing the impact of drought events, in all habitats during the 1988 drought and in the SI and AG habitats during the 1992 drought, radial growth was more negatively affected than height growth. However, in each of the habitats but most particularly in $\mathrm{OP}$ and $\mathrm{AG}$, height growth was more negatively impacted by the 1997 drought event than radial growth. We speculate that severe drought events eventually takes a toll on height growth and this may be manifested as leader dieback.

Chhin et al. [5] examined the radial growth response to climate in mature spruce island trees. This study provides the basis for examining whether there are any age-dependent radial growth responses to climate in spruce islands. In the current study, although there were no statistically significant relationships at $P<0.05$, radial growth of SI seedlings showed the strongest relationships to June $(t)$ precipitation and temperature. Chhin et al. [5] reported that the radial growth of mature spruce island trees showed a positive relationship with September $(t-1)$, May $(t)$, June $(t)$, and July $(t)$ precipitation; and a negative relationship to July $(t-1)$, June $(t)$, and July $(t)$ mean temperature. This comparison of the radial growth of young versus mature spruce island trees suggests young trees are more affected by direct and indirect moisture stress in a narrower climatic window; i.e., during the wettest month of the growing season.

The negative response of height growth of OP seedlings to September $(t-1)$ precipitation is difficult to explain since inverse relationships with precipitation are generally uncommon in arid sites [9]. However, it has been postulated that an inverse relationship with precipitation in autumn may suggest that drought stress contributes to winter hardening [9]. The role of drought stress in promoting winter hardening would be particularly important for OP seedlings since they are more vulnerable to increased exposure to wind and snow abrasion during winter versus the sheltered microclimates of SI and AG seedlings. For instance, wind and snow abrasion have been shown to influence the height growth of open grown spruce at its northern limit of distribution at the tree-line in Churchill, Manitoba [26]. 


\section{CONCLUSION}

The growth-climate relationships found in our study suggest that growth of white spruce seedlings in a forest-prairie ecotone of western Canada is conditioned primarily by direct moisture stress during the wettest month of the year, namely June $(t)$ precipitation. Seedling growth also responded secondarily to moisture stress indirectly induced by high temperatures in June $(t)$. These results together support the general understanding that the southern limit of conifer species is controlled mainly by moisture stress either directly due to low precipitation or indirectly due to temperature-induced drought stress. Further studies examining the growth of juvenile trees in response to climate would provide a more comprehensive picture of growth-climate relationships at all developmental stages versus the traditionally skewed focus on old trees.

Acknowledgements: This study was funded through a Natural Sciences and Engineering Research Council of Canada (NSERC) Postgraduate Scholarship to $\mathrm{S}$. Chhin, and a research grant from Global Forest to G. G. Wang. We thank M. Kreiner for her assistance in the field data collection; and K. Schykulski and H. Hernandez of Manitoba Conservation for their logistic support. We thank D. Hibbs (Associate Editor) and two anonymous reviewers for their constructive comments to a previous version of the manuscript.

\section{REFERENCES}

[1] Barber V.A., Juday G. P., Finney B.P., Reduced growth of Alaskan white spruce in the twentieth century from temperature-induced drought stress, Nature 405 (2000) 668-73.

[2] Bird R.D., Ecology of the Aspen Parkland of Western Canada in Relation to Land Use, Canada Department of Agriculture, Research Branch, Publication 1066, Ottawa, Ontario, 1961.

[3] Chhin S., Wang G.G., Spatial and temporal pattern of white spruce regeneration within mixed-grass prairie in the Spruce Woods Provincial Park of Manitoba, J. Biogeogr. 29 (2002) 903-912.

[4] Chhin S., Wang G.G., The effect of sampling height on dendroclimatic analysis, Dendrochronologia 23 (2005) 47-55.

[5] Chhin S., Wang G.G., Tardif J., Dendroclimatic analysis of white spruce at its southern limit of distribution in the Spruce Woods Provincial Park, Manitoba, Canada, Tree-Ring Res. 60 (2004) $31-43$.

[6] Copenheaver C.A., Abrams M.D., Dendroecology in young stands: case studies from jack pine in northern lower Michigan, For. Ecol. Manage. 182 (2003) 247-257.

[7] Drobyshev I., Nihlgård B., Growth response of spruce saplings in relation to climatic conditions along a gradient of gap size, Can. J. For. Res. 30 (2000) 930-938.

[8] Farrar J.L., Trees in Canada, Fitzhenry and Whiteside Ltd., Markham, Ontario, 1995.

[9] Fritts H.C., Tree Rings and Climate, Academic Press, London, UK, 1976.

[10] Gamache I., Payette S., Height growth response of tree line black spruce to recent climate warming across the forest-tundra of eastern Canada, J. Ecol. 92 (2004) 835-845.

[11] Groot A., Effects of shelter and competition on the early growth of planted white spruce (Picea glauca), Can. J. For. Res. 29 (1999) 1002-1014.

[12] He J.-S., Zhang Q.-B., Bazzaz F.A., Differential drought responses between saplings and adult trees in four co-occurring species of New England, Trees 19 (2005) 442-450.
[13] Hogg E.H., Hurdle P.A., The aspen parkland in western Canada: a dry-climate analogue for the future boreal forest? Water Air Soil Pollut. 82 (1995) 391-400.

[14] Houghton J.T., Ding Y., Griggs D.J., Noguer M., van der Linden P. J., Dai X., Maskell K., Johnson C.A. (Eds.), Climate Change 2001: The Scientific Basis, Cambridge University Press, Cambridge, UK, 2001.

[15] Kozlowski T.T., Kramer P.J., Pallardy S.G., The Physiological Ecology of Woody Plants, Academic Press, San Diego, California, 1991.

[16] Lane C.J., Reed D.D., Mroz G.D., Liechty H.O., Width of sugar maple (Acer saccharum) tree rings as affected by climate, Can. J. For. Res. 23 (1993) 2370-2375.

[17] Lieffers V.J., Stadt K.J., Navratil S., Age structure and growth of understory white spruce under aspen, Can. J. For. Res. 26 (1996) 1002-1007.

[18] Lloyd A., Growth of foxtail pine seedlings at treeline in the southeastern Sierra Nevada, California, USA, Ecoscience 5 (1998) 250257.

[19] Nkembirim L., Weber L., Comparison between the droughts of the 1930s and the 1980s in the southern Prairies of Canada, J. Clim. 12 (1999) 2434-2450.

[20] Rizzo B., Wiken E., Assessing the sensitivity of Canada's ecosystems to climate change, Clim. Change 21 (1992) 37-55.

[21] Rowe J.S., Forest Regions of Canada, Canadian Forest Service, Department of Fisheries and the Environment, Publication 1300, Ottawa, Ontario, 1972.

[22] Sauchyn D.J., Beaudoin A.B., Recent environmental change in the southwestern Canadian Plains, Can. Geogr. 42 (1998) 337-353.

[23] Schykulski, K., Moore J., Spruce Woods Provincial Park: prairie management plan, Manitoba Department of Natural Resources, Winnipeg, Manitoba, 1997.

[24] Shabbar A., Skinner W., Summer drought patterns in Canada and the relationship to global sea surface temperatures, J. Climate 17 (2004) 2866-2880.

[25] Scott P.A., Bentley C.V., Fayle D.C.F., Hansell R.I.C., Crown forms and shoot elongation of white spruce at the treeline, Churchill, Manitoba, Canada, Arct. Alp. Res. 19 (1987) 175-186.

[26] Scott P.A., Hansell, R.I.C., Erickson, W.R., Influences of wind and snow on northern tree-line environments at Churchill, Manitoba, Canada, Arctic 46 (1993) 316-323.

[27] Stokes M.A., Smiley T.L., An Introduction to Tree-ring Dating, The University of Arizona Press, Tuscon, Arizona, 1996.

[28] Szeicz J.M., MacDonald G.M., Age-dependent tree-ring growth responses of subarctic white spruce to climate, Can. J. For. Res. 24 (1994) $120-132$

[29] Thomas S.C., Winner W.E., Photosynthetic differences between saplings and adult trees: an integration of field results by metaanalysis, Tree Physiol. 22 (2002) 117-127.

[30] Thomson A.J., McMinn R.G., Height growth rates of young white spruce and lodgepole pine, Can. J. For. Res. 19 (1989) 257-261.

[31] Vetaas O.R., Micro-site effects of trees and shrubs in dry savannas, J. Veg. Sci. 3 (1992) 337-344.

[32] Wang T., Hamann A., Spittlehouse D.L., Aitken S.N., Development of scale-free climate data for western Canada for use in resource management, Int. J. Climatol. 26 (2006) 383-397.

[33] Wilkinson L., SYSTAT: The System for Statistics, SYSTAT Inc., Evanston, Illinois, 1990.

[34] Yamaguchi D.K., A simple method for cross-dating increment cores from living trees, Can. J. For. Res. 21 (1991) 414-416.

[35] Zoltai S.C., Southern limit of coniferous trees on the canadian prairies. Information Report NOR-X-128, Canadian Forestry Service, Edmonton, Alberta, 1975. 